\title{
Mary Douglas and Institutions
}

Dean Pierides

University of Stirling

d.c.pierides@stir.ac.uk

Graham Sewell

University of Melbourne

gsewell@unimelb.edu.au

To be published in S. Clegg \& M. Pina e Cunha (Eds.), Management, Organizations and Contemporary Social Theory, Routledge.

\begin{abstract}
We provide reasons why researchers of business and management who are interested in how institutions are related to organization would want to read and use the work of Mary Douglas. One of the central problems about which management and organization theorists still debate is the extent to which the structure of institutions and organizations determines the agency afforded to individuals. We show how Douglas makes space for a treatment of institutions that avoids the usual retreat to methodological individualism that characterises these debates. This holds out the promise of reinvigorating organisational analysis in a manner that is in step with calls for focusing on organization as a way of life and with calls for revisiting the classics.
\end{abstract}

Keywords: Mary Douglas, institutions, rational agency, methodological individualism

Dean Pierides is Lecturer in Business and Management at the University of Stirling, UK. He was awarded his BA from the University of Pennsylvania, and DipEd, MEd and PhD from the University of Melbourne. He was previously a visiting scholar at Copenhagen Business School and Lecturer in Organisations and Society at the University of Manchester. His research is about how organisations deal with uncertainty, with a focus on government agencies that are responsible for emergencies and disasters, whether natural, financial or otherwise.

Graham Sewell is Professor of Management and Associate Dean, Research in the Faculty of Business \& Economics, University of Melbourne. He received his BSc (hons) and PhD in urban planning from Cardiff University and has previously held appointments at the University of Manchester and Imperial College, London. He has also held visiting appointments at several institutions including UC Santa Cruz, UC Berkeley, and Pompeu Fabra, Barcelona. He is best known for his work on organizational surveillance. 


\section{Chapter objectives}

We present a way of ordering Mary Douglas's thinking that demonstrates its continued relevance for institutional approaches to understanding organization. We extend the ways in which Douglas's writing on institutions has been used for this purpose by considering how her notions of Grid-and-Group allowed her to develop critiques of rational agency and methodological individualism.

The chapter discusses:

- The limited manner in which the new institutionalists have so far made use of Douglas's ideas and what is lost by persisting with this restricted reading

- How the insistence that there is one rationality against which all others can be measured prevents institutional analysis from understanding its own cultural biases

- How Douglas's Grid-and-Group heuristic device avoids a retreat to methodological individualism and what is gained from using it

- How Barnard's organization theory is closer to Douglas's understanding of a way of life than it is to any of the new institutionalists, whether in economics or sociology

- One way to work through select texts from Douglas's writing and proposes how to relate these texts to concepts and problems in organizational institutionalism

\section{Introduction}

'In current institutional theory an institution is defined as a system of rules. Since the rules may arise spontaneously in response to a variety of problems, and perform many functions without any single overall objective, "institution" is to be distinguished from "organization" when that refers to a purposive arrangement for achieving a specific goal' (Douglas, 2013a, p. 36).

If one were asked to summarise in a single sentence the central concern in all of Mary Douglas's scholarship it would be difficult to improve on the following: '[T] he relation between forms of association and the forms of moral judgment that ratify the former' (Douglas as cited in Fardon, 1987, p. 4). The simplicity of this core argument belies the richness of Douglas's oeuvre. Strongly influenced by the idea that classifications are social conventions (Durkheim \& Mauss, [1903] 1963), Douglas (1986a) develops her own powerful theory of classification, one that has been picked up by scores of organizational scholars who study institutions. However, most of these scholars have only ever used her ideas superficially and largely in the absence of the broader theoretical edifice in which these emerge (for a discussion of this shortcoming see: Logue, Clegg, \& Gray, 2016). In light of this, the purpose of this chapter is to expand the scope of how Douglas's ideas might be used by organizational scholars interested in institutions.

Margaret Mary was born on 25 March 1921 in San Remo and died on 16 May 2007 in London. She was raised by her mother's parents after being sent to Devon at the age of five while her parents were stationed in Burma with the British civil service. Though it was common for children of civil servants in the Far East to be sent home at such a young age, this did affect Douglas in a variety of ways about which she would write throughout her life. Living with her grandparents she developed what she calls a 'feeling for hierarchy', ${ }_{1}$ after experiencing the 'hierarchical home' (Douglas, 2013b, p. 299). When her mother died in 
1933, she and her sister were taken back into her father's care and they were transferred to the Sacred Heart Convent in Roehampton. In this schooling system her 'feeling' for hierarchy was further intensified and the difference between life at home and life in the convent provided a stark contrast; implicit rules in the former, and explicit rules in the latter.

At university, she choose to study Philosophy, Politics and Economics at Oxford and, following her graduation in 1942, she was mobilised into the Colonial Office as part of the war effort. Whilst on post, she met various anthropologists and through reading their work became increasingly interested in anthropology. She returned to Oxford in 1946 to study the subject at the same time as E. E. Evans-Pritchard had been appointed as Chair of Social Anthropology. In our chapter, we describe how Evans-Pritchard's ideas would allow her to theorise the feeling for hierarchy she had developed intuitively in her earlier life. In 1949, as part of her doctoral study, Douglas went to the Belgian Congo to do fieldwork among the Lele of the Kasai. She moved to University College London in 1951, married James Douglas and in 1953 completed her doctorate. At UCL, where Daryll Forde was head of department, she first published work that was based on her African fieldwork, later extending her ideas into new areas, now publishing about food and consumption theory.

Douglas remained at UCL until 1977, after which she moved to the United States. There she was Research Scholar and later Director of Research on Culture at the Russell Sage Foundation in New York. This facilitated her collaboration with political scientist Aaron Wildavsky on the topic of risk perceptions and environmentalism before she moved again for a joint appointment across Humanities and Religious Studies at Northwestern University in 1981. At Northwestern, she returned to some of her earlier interests in religion and theology, whilst continuing to develop her ideas about hierarchy in new and interesting directions. She was a visiting professor at Yale and Princeton. Douglas left Northwestern in 1985 but continued to publish. She was awarded Commander of the Most Excellent Order of the British Empire in December 2006 shortly before her death.

We do not aim to provide a précis that readers would use in place of Douglas's original texts. Instead, we start with a discussion about how her ideas have been taken up by organizational scholars who study institutions, much in the same manner as a newcomer to the study of business and organizations might encounter her work. Next we discuss what is lost by not reading her work directly. We use this format so that we can provide a guide for how to approach Douglas's ideas directly and so that we can point to secondary literature that might be relevant for studying institutions. Our aim in doing this is to build on Douglas's legacy in the broadest way possible so that we can make room for new organizational research on institutions that will be inspired by her important contributions to the social sciences. By the same token we will avoid providing the customary list of 'suggestions for future research' because we want to reinforce the message that Douglas's books should be consulted directly by anyone seeking inspiration. If, as Douglas argues, organizational actions are understood to be related to the correspondence of forms of association and forms of moral judgment then we hope our reader can see how Douglas provides us with a rich theory and method for better understanding the ethical tension between how organizations are and how they ought to be. 


\section{Why the new institutionalism has tried to do the thinking for us}

Why would someone studying the world of business and organizations be interested in institutions? If modern organizations emerge because magic, myths and superstition are increasingly replaced by processes of intellectualization and rationalization, ${ }^{2}$ then understanding how the rise and fall of different institutions has influenced the development of the modern world would help us better understand why organizations are the way they are. By extension, it could also help us understand why organizations are not different from how they are now or it could even help us work out how they might be different. We could simply say that understanding the institutionalised organization of life can help us make a difference (e.g. March \& Olsen, 1984). Trying to understand these processes of rationalization better, Meyer \& Rowan (1977) concluded that the formal organizational structures that sustain the coordination and control of activities of organizations arise in highly institutionalised contexts, as is evident in their incorporation of prevailing practices and procedures. This, in turn, increases the legitimacy and long-term survival of organizations, even if adopting these practices and procedures goes against the short-term efficacy of doing something else. They proposed that these rationalised myths arise in an institutional context alongside complex networks of social organization and exchange, which subsequently also support and sustain the diffusion of these myths. Since the publication of Meyer \& Rowan's (1977) landmark article there has been an ever-increasing interest amongst organizational scholars to understand the role of institutions in the world of business and organizations.

In their introduction to the influential edited volume The new institutionalism in organizational analysis, DiMaggio \& Powell (1991) sought amongst other things to differentiate this new institutionalism of organization theory and sociology from the new institutionalism of economics and public choice. They draw on two main arguments from Douglas's book titled How Institutions Think (1986a). ${ }^{3}$ First, they build on her critique that the behavioural conventions of rational actors, on which economists and public choice theorists rely, are on their own too unstable and unsustainable to be the starting point and foundation for an institution. Her critique poses a series of questions that would be difficult for rational choice theorists to adequately answer. What prevents individuals from repeatedly misbehaving in a haphazard manner? What prevents an individual from altering a convention on a whim? And what prevents individuals from free riding? Douglas proposes that it is the relationship between behavioural conventions and cognitive conventions that can provide continuity and order and that under certain conditions, an institution can emerge out of this relationship.

Second, in How Institutions Think, Douglas provides a theory which explains what the conditions for the emergence of an institution actually are, and, why understanding them is a necessary component for analysing the origins and continuity of any institution. Since individual people in Douglas's theorisation do not determine the fit between conventions and the order of the universe, new institutionalists can follow her lead and exclude from their definition of institutions 'any purely instrumental or provisional practical arrangement that is recognized as such' (Douglas, 1986a, p. 46). Drawing on the ideas of both Émile Durkheim and Ludwik Fleck, ${ }^{4}$ Douglas encourages us to think of an institution as a 'legitimized social grouping', its legitimacy derived from its 'fit with the nature of the universe' (Douglas, 1986a, p. 46). This analogy, between behavioural and cognitive conventions, on the one hand, and the natural order of the cosmos for a given group of people, on the other hand, is what Douglas means when she refers to a 'naturalizing analogy' (see: 1986a, pp. 48, 50, 52). 
Institutional theorists after the publication of DiMaggio \& Powell's edited volume have demonstrated a strong preference for using only Douglas's (1986a) How Institutions Think, usually in a perfunctory manner, failing to explore the full implications of what it means for an analogy to become naturalized in the manner she theorizes. This is unfortunate, since, as we argue in this chapter, there is more to Douglas's thought in that particular book, and much more than that particular book on its own would reveal. One notable exception is a recent paper by Logue, Clegg \& Gray (2016) that focuses on what Douglas's core arguments can contribute to the theorizing of institutional logics. Next, we briefly introduce what institutional logics are, we summarise the advances that Logue et al. (2016) make using Douglas's ideas and then we consider the broader contributions of How Institutions Think in order to identify just how much more we could glean from this book alone.

Scholarship on institutional logics predominantly takes as its starting point the chapter by Friedland \& Alford (1991) titled Bringing Society Back In: Symbols, Practices, and Institutional Contradictions published in the DiMaggio \& Powell edited book that we mentioned above. In that chapter, Friedland \& Alford (1991) argued that institutional logics are the symbolic and material patterns that organize the institutionalized social world and that these logics constitute 'society as a potentially contradictory interinstitutional system' (Friedland \& Alford, 1991, p. 240), an idea that was later developed to provide a meta-theory of society which aims to explain 'actors' choices for sensemaking, the vocabulary they use to motivate action, and their sense of self and identity' (Thornton, Ocasio, \& Lounsbury, 2012, p. 2). ${ }^{5}$ Like DiMaggio \& Powell (1991), Friedland \& Alford draw on Douglas's critique of rational choice theory and her insistence on the importance of cognition but they also criticise Douglas for under-theorising the incompatibility of different institutions, attributing this lacuna to her concern with establishing 'the basis of social solidarity in shared categories of knowledge' (Friedland \& Alford, 1991, p. 262 fn. 22). Boxing Douglas in the consensus category, within a consensus versus conflict dualism is, perhaps, too hasty.

As Mary Douglas's biographer, Richard Fardon (1999, pp. 210-211), tells us, How Institutions Think is only one side of the coin. Her essay on Cultural Bias (Douglas, 1978; 1982b, pp. 183-254) is the other. In fact, if we start with yet another of her essays titled Passive Voice Theories in Religious Sociology (Douglas, 1982b, pp. 1-15) and couple this with Cultural Bias, what we start to see is that accountability is foundational for social solidarity and it provides the mechanism by which voluntary, intended agency is granted by everyone, collectively, to every individual. This mutually agreed form for individual responsibility is the flip side of the attribution of blame.

Logue et al. (2016, p. 1602) remind us that the original conception of institutional logics that was developed by Friedland \& Alford was centrally concerned 'with how analogies ground new practices and narratives achieving naturalness' but that 'this insight has faded from more recent institutional work'. Although some organizational scholars have used analogies to study institutions (e.g. Cornelissen, Holt, \& Zundel, 2011; Etzion \& Ferraro, 2010), their accounts have been much narrower in their scope than Logue et al. (2016) suggest they could be if we follow Douglas instead. Where organizational scholars have so far treated analogies only based on representations-in-use (e.g. text, images, etc.), Douglas (1986a, p. 45) would urge us to consider analogies as foundational for institutions, 'in reason and in nature'. In short, where organizational scholars have thus far merely treated analogies as discursive formations that accompany institutions, we think that organizational scholars could go further and study them as cosmologies on which all institutional life is founded. Importantly, this 
expansion of representation beyond the bounds of the narrow psychologism of individual cognition is an invitation to explore how membership of social entities - in this instance, organizations - involves a consideration of actions that are not simply the enactment of schemas or logics. In short, Douglas is advocating a European social anthropology of institutions drawing on Durkheim and Mauss rather than a US cultural anthropology of institutions drawing on Boas and Benedict. While the former would take its object of study as the social collective itself, the latter has a tendency to reduce the social to an epiphenomenon of rules of behaviour as they apply to individuals.

\section{The Intellectual Antecedents of a Social Anthropology of Institutions}

The intellectual backdrop to what was happening in British anthropology before World War II can be conveniently caricatured as a struggle between Malinowski's functionalism at the LSE and an emerging structuralism at Oxford (see Goody, 1995, pp. 68-76; Kuper, 1983, pp. 66-93). Douglas went up to Oxford in 1939 to study as a member of the Society for Home Students (later St Anne's College), which allowed her to attend lectures and tutorials across the university, including those given by Alfred Radcliffe-Brown who had been appointed to the foundational chair in social anthropology two years earlier.

The attempt to establish a true "science of the social" at Oxford was self-consciously a rejection of the individualism of Malinowski's Argonauts of the Western Pacific (1922). Here Malinowski aimed to show that the Trobriand Islanders had customs and laws that were entirely rational insofar as they met an individual's need to make sense of their world. Describing it as a 'classic of descriptive ethnography' (1951, p. 93), Malinowski's student Evans-Pritchard was nonetheless critical of this effort because it treats 'only a part of social life for particular and limited problems of investigation, taking the rest into consideration only in so far as it is relevant to these problems' (1951, p. 96); a kind of functional analysis that he similarly identifies in Margaret Mead's Coming of Age in Samoa (1929).

Between 1926 and 1938, Evans-Pritchard was doing fieldwork amongst the Azande in Sudan and the Nuer in Kenya. Unlike prior anthropologists, such as Malinowski, who studied much smaller, island populations in Oceania, Evans-Pritchard and his contemporaries who were studying African societies were confronted with the vast governmental systems of tribes and nations which colonial authorities were having trouble disciplining. The lack of centralised political institutions amongst the Nuer, for example, is one of the reasons that EvansPritchard was led to abandon the Malinowskian mode of generalising from single societies and toward Radcliffe-Brown's comparative approach. Evans-Pritchard and Fortes (see Goody, 1995, pp. 58-67), however, also departed from Radcliffe-Brown's position by emphasising 'the lineage as part of the system of political relationships, rather than as a mode of organizing personal relationships... [so that the] term "social structure" came to connote the structure of relationships between groups and, in Fortes's work, offices, rather than between persons' (Kuper, 1983, p. 86). Radcliffe-Brown and Evans-Pritchard also disagreed about whether anthropology was to be considered a science or part of the humanities.

The 'new paradigm', as Kuper (1983, p. 84) has referred to it, thus ushered structuralism into British anthropology creating a rift between those who followed Malinowski at the LSE and those who followed the Oxford tradition established by Radcliffe-Brown and developed further by Evans-Pritchard and Meyer Fortes. Of course, it is worth noting that in spite of 
their differences what both Malinowski and Radcliffe-Brown were doing was constituted as the science of society, a commitment which many succeeding generations of cultural anthropologists would drop, thereby returning anthropology to the humanities. The new paradigm marked a shift from function to meaning. Structural analysis meant 'the integration of abstractions from social life' (Evans-Pritchard, 1951, p. 96). It was a shift from 'the concrete, institution-based functionalism of Malinowski... [to] a sociological, structuralist position' (Kuper, 1983, p. 97). This new British structuralism was later to be developed by Edmund Leach, Rodney Needham, and even later by Mary Douglas (Kuper, 1983, p. 169).

Like Durkheim, Evans-Pritchard aimed to show that societies otherwise considered primitive are not irrational and plagued by superstition. Instead, the people in these societies follow a logic that makes sense to them, that is rational to them. If an anthropologist could understand their witchcraft, they could explain misfortune rather than treat peoples' belief about it as irrational. In adopting a sociological position, anthropologists following Radcliffe-Brown took social facts, in Durkheim's sense, to be central to understanding this system (Stocking, 1984, 1995). Social life is analogous to organic life in so far as the function of a social institution is the correspondence between that institution and the conditions of the existence of the social. Institutions are situated within a social structure that is made up of individuals who are finitely connected into an integrated whole (see Evans-Pritchard, 1951, p. 54; Radcliffe-Brown, 1935, p. 394).

Where Evans-Pritchard (1965, p. 111) parted ways with Durkheim is in believing that anthropology 'deals with relations, not with origins and essences' as Durkheim did. We now turn to Douglas's (1980) book on Evans-Pritchard to show how she takes all of these different sociological elements in a direction that is particularly useful for investigating institutions. Evans-Pritchard was, of course, hugely influential in Douglas's thinking, a personal friend of hers and an intellectual compass of sorts. Her book on Evans-Pritchard was written after both of the two influential books in which she synthesizes her ideas, Purity and Danger (1966) and Natural Symbols (1970), and must therefore be read as a retrospective account (Fardon, 1999, p. 33). According to Fardon (1999, p. 26), 'at different stages in the development of her own thought Mary Douglas was able to turn back to Evans-Pritchard to experience again the recognition that he had been there before her in important respects'. Although her 'interpretation of what was of value in Evans-Pritchard work... is one with which few will agree' (Schneider, 1981, p. 721) and for some even 'turns out to resemble Mary Douglas' herself (Beidelman, 1980), we would suggest that Douglas's work can be approached from a different point of view.

Interestingly, the second chapter of her book on Evans-Pritchard focuses on 'human mental faculties' and can be seen as a restorative account of British and French psychology for the purposes of the sociology of knowledge. The former had failed 'to develop a sociological dimension to their experimental thinking' and the latter had failed to 'benefit from the British methodological advances' (Douglas, 1980, p. 28). Evans-Pritchard, she argues, shows us a way forward. What differentiates Evans-Pritchard from any other scholar focusing on 'the power to suspend attention... was his confidence that the selective principles were to be found in social institutions' (1980, p. 27). This was precisely the argument made by Durkheim and Mauss and Douglas tells us that Evans-Pritchard's life can therefore be presented as a tribute to them. ${ }^{6}$ The focus on mental faculties might seem ridiculous were it not for this point which directs us to the relationship between cognition and institutions which Douglas herself would later come to tackle. 
If philosopher Immanuel Kant was right that the mind could organize immediate experience, how can any knowledge system be explained without defaulting to a transcendental divinity or collapsing all explanation into the individual? ${ }^{7}$ Durkheim resolves the tension between classical empiricism and Kantian apriorism by rendering epistemology sociological. This was Durkheim's great insight. His ingenious solution is summarised in the conclusion of a book Durkheim wrote with his nephew Marcel Mauss which aimed to demonstrate that primitive classifications are essentially no different from modern classifications: 'they are systems of hierarchized notions' and they 'have a purely speculative purpose' (Durkheim \& Mauss, [1903] 1963, p. 81). Taking How Institutions Think as our starting point, we can start to see that Douglas picks up on Durkheim's effort to understand pre-modern classification and she extends this to the modern world. What needs to be understood in any specific analysis is how a classificatory enterprise is matched with social requirements, ultimately producing the foundations of a sociological epistemology (Douglas, 1986a, pp. 62-63).

Almost an entire century later, the problem that Evans-Pritchard poses about human mental faculties still haunts us. Psychologists, economists and rational theorists of all flavours still insist in various ways that there is one rationality against which all others can be measured. Ultimately, however, both institutions and organizations are epiphenomena of ongoing human habits and experience (cf. Dewey, 1922). But according to Kant's formulation, experience is structured by a priori categories and intuition that comprise the necessary and universal basis for all knowledge. The link then must be that attention is controlled by principles that are derived from interests, which can only be constituted in society, not the individual mind. ${ }^{8}$ By attention, Evans-Pritchard probably meant something similar to what organizational institutionalists mean (e.g. Thornton \& Ocasio, 2008, pp. 113-114), since he was in conversation with neurologists and psychologists such as Frederick Bartlett, Henry Head and Charles Sherrington. However, the mechanism Evans-Pritchard was proposing undermines the one the new institutionalists would inherit from psychology because it locates interests in society rather than the individual mind. Accordingly, the 'contrast between primitives and ourselves is much exaggerated by pretending that we think scientifically all the time... [and to] prevent that error the proper method is to compare like with like, our everyday thought with their everyday thought' (Douglas, 1980, p. 31). ${ }^{9}$

What can be gleaned from Douglas's interpretation of Evans-Pritchard's ethnographic work that is helpful for understanding institutions? Douglas tells us that Evans-Pritchard was interested in how the things that the Azande and the Nuer do in moments of misfortune can be used to study accountability. Since misfortune must be explained somehow, people resort to systems that require them to either blame or accept responsibility. The movement from consciousness to action is thoroughly institutionalised and accordingly requires the invocation of existences and powers that differ from one system to another.

Methodologically, the researcher traces this accountability as it surfaces. When institutions are guarded an 'awesome cosmos' is established and 'the initial convention is buried' (Douglas, 1999, p. xv). As Douglas says about Durkheim's model, delusion is necessary and this entire setup creates the delusion that institutions confer certainty. The analyst who idly goes along with this implicit assumption fails to understand the process by which institutions are created and maintained. 


\section{Grid-and-Group}

'It is easy to be scathing about whether communities divide into hierarchical groups, egalitarian groups, individualist groups: They do not, and no one ever said they do' (Douglas, 1999, p. 225).

In Purity and Danger (1966), Douglas built on the critique of 'primitive mentality' we have outlined above (Evans-Pritchard, 1934) and famously showed the universality of cognitive blocks on matter that is 'out of place'. She showed that rituals of cleanliness in contemporary households are underwritten by classification in much the same way as rituals related to defilement in societies described as primitive. In other words, from the point of view of studying social controls on institutionalised classification, there is no difference between primitive and contemporary societies. All institutions and organizations impose a classificatory order but the specific classifications in each do vary. What was missing was a parsimonious tool with which comparisons can be made. This new problem enters Douglas's repertoire in conversation with the work of sociologist of education Basil Bernstein.

Douglas took inspiration from a paper delivered by Bernstein at the London Institute of Education, titled 'Ritual in education'. Bernstein's argument was that speech acts were not psychologically determined but rather that forms of speech are subjected to controls on social position and social individualisation. He had developed a model for understanding cultural transmission that struck a chord for Douglas because it lent credence to the argument that one did not need to go and study remote peoples to learn about what it means to be human. It also promised to introduce a potential dynamism to her earlier model. Thus, after meeting Bernstein, Douglas proceeded to apply his ideas about 'speech, thought and social structure to the study of religion' (Douglas, 2001, p. 113), thus updating her earlier work on purification. Starting with Natural Symbols (1970), which was a product, at least in part, of many discussions with Bernstein, she began to revise one of the central theses of Purity and Danger. Bernstein urged her to consider those people who can go on with few concerns about matter that is out of place; where do they belong? This is when she starts to differentiate classification systems.

In this work we start to see that values, the division of labour and social organization are differently upheld depending on the culture that produced them as classification systems. Throughout different editions of the book, features of this 'grid-group' typology as she would eventually call it, draw inspiration from different aspects of Bernstein's work. What ties them together however is the work of Durkheim, especially his book on suicide (Durkheim, 1951). The common influence can be summarized as follows: 'different forms of suicide are the products of different degrees of group regulation (or constraint) and group bonding (or affection)' (Richards, 2008, p. 406). As its name suggests, the grid-group schematic has two dimensions for grounding ideation in social life. Fardon summarises how these appeared in the first edition of Natural Symbols:

'The first of these, "group" - the experience of a bounded social unit - ...is prerequisite to the classic instance of the Durkheimian hypothesis in which society is expressed through ritual... [G]roup is independent of the second variable, which Douglas calls "grid"... On this first definition, grid consists of "rules which relate one person to others on an ego-centred basis" (Douglas, 1970, p. viii, as cited)... Group evokes boundary, an enclosing 
circle; grid may either picture the individual as a nodal point from which relations radiate, or else place the individual within a "cross-hatching" of rules, distinctions and regulations. The thought of individuals grounded in these social dimensions is channelled into the "grooves" worn by the thoughts of previous residents of the same institutional space. The formal characteristics of both the "thought-style" and the institutional space within which it arises are similar' (Fardon, 1999, p. 111).

This sets up three conditions: group and grid, so that boundaries and internal order are well established; group not grid, so that boundaries are rigid but there is internal disarray; and, grid not group, so that ego-centred networks prevail. In the second edition of the book, Douglas extends this. Justification for a system of knowledge is given by a cosmology, which elaborates principles and the associated conduct that follows. ${ }^{10}$ The group dimension had to be enlarged to accommodate for the kinds of demands that Bernstein saw were being placed on students: '[t]he difference between strong boundary maintenance and weak boundary maintenance in education is analogous to the difference between ritual and anti-ritual in types of religion' (Douglas, 1996a, p. ix). This extends the central thesis of Purity and Danger in new and interesting ways, as Douglas explains in one of her many acknowledgements to Bernstein: ${ }^{11}$

'... in that study I emphasized the communication function of all boundings of experience, without facing the empirical fact that some societies persist very well without strongly bounded cognitive categories and some tolerate anomaly more easily than others. Natural Symbols is an attempt to answer questions raised by myself from the programme of the earlier book' (Douglas, 1996a, p. ix).

These changes maintain parsimony in the schema while introducing many new explanatory dimensions to it, including not least the capacity to place societies in more than one quadrant and a dynamism that accounts for different lengths of time. In sum, as we tend toward a system of shared classifications (up on the vertical axis) it becomes increasingly possible to exercise control through classification. As we tend toward the origin and toward private classification, the associated control also changes (either through brute force or strong personal relationships). The ego with respect to others (the horizontal axis) varies according to whether control is being exercised against others (left) or by others (right). In other words, control is not the same concept in all locations of the schema.

In this diagram (see Figure 1), Douglas is clear that she is reducing, re-arranging and adding to Bernstein's model but that ultimately she is returning to the intentions behind it. It is a model for 'deriving cosmology from control systems, or rather showing how cosmology is a part of the social bond, according to [three] principles' (1996a, p. 57): (1) the entire cosmos and the place of humans in it has to match up with the control system imposing it; (2) the medium of control (speech codes and rituals) interacts with the control system and (3), the coding of the medium matches up with the control system. The first of these principles, as Douglas notes, is attempting to address what Weber refers to as legitimation. When she combines this with the second and third principles, to produce the concepts of Grid-andGroup, we have descriptive tools for addressing 'the way that social pressures reach an individual and structure his consciousness' (Douglas, 1996a, p. 86). 


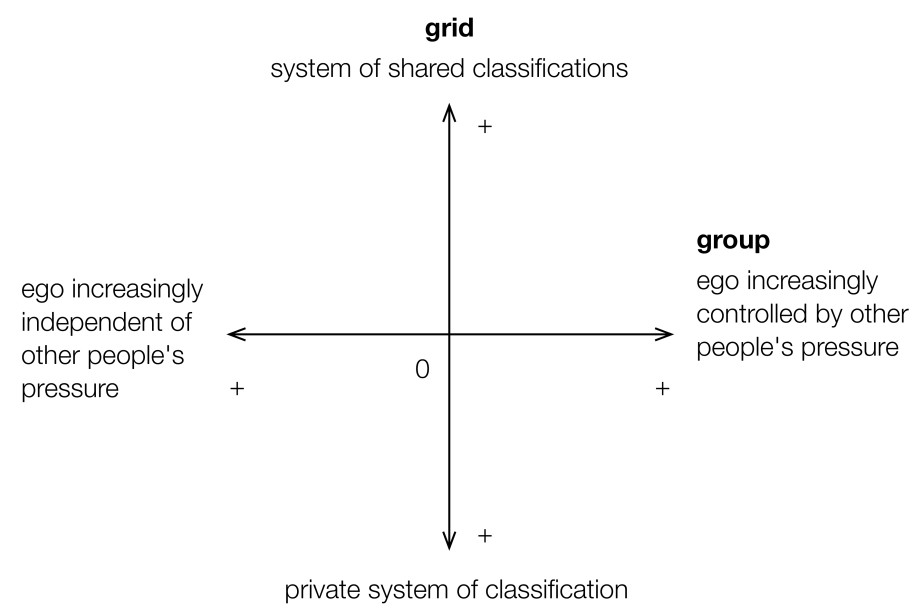

Figure 1: Grid-and-Group diagram, adapted from Douglas (1996a, p. 60)

The Bernstein-Douglas diagrams had wide-ranging influence in many different circles, not least of which, amongst a group of scholars that sought to develop this line of work explicitly (Douglas, 1982a). What does the Grid-and-Group typology do? According to Fardon (1987, p. 5) it operationalises: 'the correlations which should exist between types of social interactions and the moral and cognitive universes in which they took place. To each social environment there should be a corresponding world of ideas. "Cultural bias" would tally with social experience, and social experience could be represented in terms of the qualities of relationships and the boundedness of social networks'. For us the importance of Grid-andGroup is not that it should be deployed blindly as a tool to classify human behaviour; rather it is a compelling illustration of the explanatory importance Douglas attaches to our membership of a particular social collective when considering how we try to rationalize our behaviour with respect to others deemed to be inside or outside that social collective. In a sense this is Douglas's own attempt to deal with the familiar structure/agency dualism but in a way that makes space for a treatment of institutions that avoids a retreat to methodological individualism.

\section{Beyond Methodological Individualism and the Myth of the Rational Actor}

Melvin A. Eggers, the Chancellor of Syracuse University, wrote the foreword of How Institutions Think ${ }^{12}$ and in it he notes that the book is the product of five lectures which Mary Douglas gave as part of the Abrams Lecture series at Syracuse. ${ }^{13}$ The head of the lecture series planning committee was Guthrie S. Birkhead, Professor of Public Administration and Political Science and Dean of the Maxwell School of Citizenship and Public Affairs. The other members of the committee were the Vice Chancellor, the Dean of the School of Management, a Syracuse law professor, the Chairman of the University's Board of Trustees and the President of the Exxon Education Foundation. That Douglas would be chosen by this committee is telling of not only who respected Douglas's contributions to academic knowledge but also those whom Douglas was willing to engage with through her ideas.

The lecture series was funded by the Exxon Education Foundation in memory of Frank W. Abrams who was Chairman of the Board of the Standard Oil Company of New Jersey. Abrams is worth mentioning in this context because of his commitment to responsible and 
professional management, which he believed could be achieved when 'individual objectives... are identified with the common good' (Abrams, 1951, p. 34). According to Swanson (2008, p. 235), Abrams's call for executives to accept their responsibilities to society by adopting a professional attitude toward a wide variety of stakeholders has been credited with influencing the development of stakeholder theory and the role of executive leaders in corporate social responsibility. Abrams's commitment to civic duty echoes a form of responsible management that one of his contemporaries, Chester Barnard, tried to develop throughout his career. Barnard made some of the most important contributions to our understanding of management and organizations to date (Perrow, 1986), but his work has largely fallen out of favour. Douglas saw similarities in this part of Barnard's work with her own interests but identified major shortcomings in the way that one of Barnard's central concerns had been interpreted by subsequent generations of economists and management scholars. She took them on and tried to vindicate Barnard.

In the Spring of 1988, economist Oliver E. Williamson, who just over two decades later would become the recipient of the Sveriges Riksbank Prize in Economic Sciences in Memory of Alfred Nobel, held a visiting post as Professor of Economics and Transamerica Professor of Business Administration at the University of California, Berkeley. As is often customary with such appointments, he was asked to convene an interdisciplinary seminar, the theme of which became Chester Barnard's classic book The Functions of the Executive (1938). The contributions to this seminar were eventually published as a book titled Organization Theory: From Chester Barnard to the Present and Beyond (1990; expanded edition published in 1995). Alongside contributors more easily identifiable as management scholars, such as James March, Dick Scott, Glenn Carroll and Jeff Pfeffer, Mary Douglas has a chapter titled Converging on Autonomy: Anthropology and Institutional Economics. It is the 1995 version we refer to, although it was also reproduced under the title Autonomy and Opportunism in her book, Risk and Blame: Essays in Cultural Theory (1992).

Douglas's focus on Barnard is, at first blush, rather unpromising, for what could such a venerable commentator possibly offer for today's organizational researcher? According to Douglas, however, what Barnard was trying to achieve - an adequate theory of the interaction of individuals with the organization they work in - had largely eluded us for decades. Still, Barnard did offer a rudimentary theory that links the purposes of members of organizations with the purposes of their organizations. The problem for Douglas is that readers of Barnard's work had relied on an economistic view of human agency that has achieved its most developed status in the transactions costs approach of Oliver Williamson. ${ }^{14}$ As such, how homo economicus maintains his autonomy in an organization for them is matter of rational choice: i.e., establishing equilibrium between the utility of self-interested behaviour and the pursuit of collective goals. Doing so bespeaks a methodological individualism founded on an $18^{\text {th }}$ century notion of autonomy that is still evident in economics and social theory alike where people rationally choose their ideas, unlike primitives who are bound by the stultifying effects of culture. Such interpretation went against the grain of Douglas's critiques of rational agency and methodological individualism, which we introduced above. It also betrays Barnard's original attack on homo economicus and his attempt to develop organization theory that is closer to Douglas's understanding of a way of life than it is to any of the new institutionalists (cf. du Gay, 2015), whether in economics or sociology. ${ }^{15}$ 
Douglas contends that this attempt to relate the structure of individual goals to the organization is founded on impossibility. This starting point gets in the way of any attempt to relate the structure of individual goals to the goals of an organized social environment, such as an organization. It is a sleight of hand because it is based on something that cannot be known: the genuine desires of the actor. Nevertheless, maintaining the conceit that economic actors behave according to some internal rational calculus of cost has undeniably been very successful, at least in a performative sense. Thus, unacceptably high costs for a particular choice will make a rational being change his or her mind about the ordering of their goals visà-vis those of the organization without the need to consider any social influences. In other words, it treats individuals' objectives as independent of those of other people or the organization. Indeed, the only environmental factors that need be considered are expressed through the price setting of the market; preferences arise mysteriously from within the individual (Wildavsky, 1987). In terms of classifying organization, the implications are stark in that we end up with Williamson's binary choice of either hierarchy or market. Douglas, however, proposes a way of classifying organizations using an anthropological approach that relies on seeing them as systems of shared meaning that afford its members more or less autonomy while simultaneously defining what that autonomy consists in.

This is where Grid-and-Group analysis comes into its own. Drawing on the work of her one time student, Gerald Mars, Douglas shows that different organizational arrangements are associated with alternative economies of reward and esteem. Although economists since Adam Smith have acknowledged that the esteem in which others hold us is part of the calculus of cost, this has been limited to economising around transactions and in this sense Williamson is simply following a venerable tradition. In contrast, Mars shows a parallel economy of personal utility can exist, based on four characteristic shared understandings of the interaction of opportunistic behaviour and mutual esteem. Importantly these play out across the dimensions of Grid-and-Group to capture the social environment that affects the relations between an organization's members by mapping onto easily apprehensible notions of structure and boundary. While Group represents where the boundary between insiders and outsiders lies, Grid is a measure of the extent to which those on the inside have to interact with those on the outside insulated from those on the inside.

An exemplary illustration of the Grid-and-Group typology in Natural Symbols (1973a) is David Bloor's (1978) analysis of how the discipline of mathematics responds to cultural differences (see also: Barnes, 1983). Bloor looks at the organization of mathematics departments in $19^{\text {th }}$ century Germany and shows that there is a correspondence between their institutional form, on the one hand, and the curriculum and their chosen research topics, on the other hand. Drawing on Lakatos's (1963) study of the way in which German mathematical departments dealt with subsequent challenges to Euler's formulae concerning complex polyhedra, Bloor shows how a group of people bound together by set of common intellectual principles deal with challenges to their world view. Much in the same way as Douglas looked at rituals of cleanliness or defilement, Bloor is able to show that organization corresponds to classification schemes.

The key insight that Bloor takes from Douglas to establish this line of institutional reasoning is that members of social groups understand the world through the categories they derive from their shared intellectual and material resources. This is where institutions crash into the messy world of human experience and here the key question arises: what happens when members of the group encounter an anomaly (or what Lakatos called a "Monster") that does 
not neatly fall into one of the existing categories they use on a day-to-day basis? For Lakatos this was a polyhedron that did not accord with Euler's formulae, which meant that the formulae themselves needed revision or the Monster had to be redefined. But what passes for a monster in nineteenth century geometry also goes for today's organizations. For example, how do we classify forms of organization that are neither captured by the rigidities of formal bureaucracy nor by the anarchy of the unfettered market? This is a challenge for organization studies and other disciplines that are so wedded to this simple binary choice. Small and isolated groups of scholars who do not have the intellectual and material resources nor the autonomy associated with the great European and North American universities (i.e., low Grid/high Group) would have good reason to fear these monsters as abominations and avoid the challenges they pose to their comfortably simple view of the world (an act of Monster Barring, as Bloor puts it). In contrast, larger and better resourced groups of scholars-wellcredentialed members of the intellectual mainstream if you like - are much better placed to accommodate monsters simply by creating new sub-disciplines with suitably revised theoretical and empirical instruments. This is, nevertheless, still a conservative strategy of high Grid/high Group that attempts to control disruption to its intellectual worldview by containing the monster, rather than by embracing it (according to Bloor an act of Monster Adjustment or, perhaps more graphically, a practice of sweeping the problem under the carpet, as Douglas describes it). This is because the autonomy of Monster Adjusters is constrained by their membership of the very community that is the source of most of their privileges. The scholars who are most receptive to the challenges posed by an anomaly, however, are those who have both the material and intellectual resources and the autonomy (i.e., low Grid/low Group) to indulge in what Bloor calls Monster Embracing activity. In this case the presence of an anomaly is not a threat to be ignored or closed down but is an opportunity for individuals to advance their career and enhance their status vis-à-vis other organizational scholars by proposing a new category of organization. Of course, if sufficient numbers come to accept this new formulation it becomes the new orthodoxy and effectively the institution has changed.

Categories are developed to address organizational problems, problems that are the product of usually implicit institutional processes. Norms then emerge from organization. If we follow Bloor's analysis of various forms of organizing which uses Douglas's Grid-and-Group typology together with Douglas's consideration of ritual, we can significantly expand the institutional analysis of categories from merely looking at vocabularies (Loewenstein, Ocasio, \& Jones, 2012), or temporally protracted rituals (Tracey \& Creed, 2017) and myths (Sewell, 2018), to capture the full anthropological richness of organizational experience. An institutional analysis of this sort would thus yield a noticeably enriched understanding of organizations and undoubtedly displace the overly determined individual extant institutional analysis inherits from the weakest assumptions of psychology and economics.

\section{Concluding Remarks: How institutions really think?}

'Nearly the whole effort of British social anthropology ... was developed under the assumption that organization results from the process of adapting categories of thought. When I write that common categories are the basis of the social bond, reviewing anthropologists castigate me for stating the obvious' (Douglas, 1995, p.

104). 
The preface that Douglas wrote for How Institutions Think provides a good a place to finish for our purposes. Here she is upfront about her attack on ideas of human cognition that lack sociological awareness and on the weaknesses of institutional analysis in economics. Indeed, as she pointedly says, 'Not just any busload or haphazard crowd of people deserves the name of society' (Douglas, 1986a, p. 9). This much is consistent with the lessons that organizational institutionalists take from the book. But she then explains that the lectures from which the book is drawn repeat ideas she had already developed in her earlier work but in the book these are restated with the aim of shedding new light on them, clarifying them, making them more persuasive and refining their delivery. Douglas goes even further and suggests that there is an important link between How Institutions Think and her previous writing to date that responds to her critics. This link is repeated at various points throughout her work, reminding us that all her different books make incremental modifications to the others. In the table below we attempt (with an obvious sense of irony) to classify her advice and the advice of her critics and commentators to produce a rough guide on how to approach the relationship between different books (for elaborated versions of many of the same points, see: Fardon, 1987, 1999; Mamadouh, 1999). This is neither a complete bibliography of Douglas's work, nor a definitive guide, it is just one way to work through select texts and relate them to concepts and problems in organizational institutionalism (see Figure 2). We present this as a thematic rather than strictly chronological approach to Douglas's writings; something that is particularly important, as she was apt to draw heavily on previous work in complex ways. We look forward to seeing institutional analyses of organization that are centrally inspired by Douglas's important ideas and hope that our discussion assists in achieving this objective.

\begin{tabular}{|c|c|c|c|}
\hline Title (Reference) & $\begin{array}{l}\text { A Description of the } \\
\text { Contribution }\end{array}$ & $\begin{array}{l}\text { Our Reflection of the } \\
\text { Contribution }\end{array}$ & $\begin{array}{l}\text { Implications for } \\
\text { Institutionalism }\end{array}$ \\
\hline $\begin{array}{l}\text { How Institutions } \\
\text { Think } \\
\text { (Douglas, 1986a) }\end{array}$ & $\begin{array}{l}\text { Establishes } \\
\text { presuppositions and } \\
\text { foundations. Points an } \\
\text { accusing finger at } \\
\text { professional blind } \\
\text { spots and rooted } \\
\text { resistance. A post hoc } \\
\text { introduction or } \\
\text { prolegomenon to Risk } \\
\text { Acceptability. How } \\
\text { Institutions Think is } \\
\text { only one side of the } \\
\text { coin. Her essay on } \\
\text { Cultural Bias } \\
\text { (Douglas, 1978; } \\
\text { 1982b, pp. 183-254) is } \\
\text { the other. }\end{array}$ & $\begin{array}{l}\text { Develops a theoretical } \\
\text { and logical anchoring } \\
\text { that presents a coherent } \\
\text { argument about the } \\
\text { social control of } \\
\text { cognition (for } \\
\text { background and } \\
\text { context, see: Douglas, } \\
\text { 2013b). Start with her } \\
\text { essay titled Passive } \\
\text { Voice Theories in } \\
\text { Religious Sociology } \\
\text { (Douglas, 1982b, pp. 1- } \\
\text { 15) and couple this } \\
\text { with Cultural Bias. } \\
\text { Accountability is } \\
\text { foundational for social } \\
\text { solidarity and it } \\
\text { provides the } \\
\text { mechanism by which } \\
\text { voluntary, intended } \\
\text { agency is granted by } \\
\text { everyone, collectively, }\end{array}$ & $\begin{array}{l}\text { An institutional theory } \\
\text { that can interpret the } \\
\text { multiple interactions } \\
\text { that individuals have } \\
\text { with the organization in } \\
\text { which they work that } \\
\text { relies on the actual } \\
\text { experiences of humans } \\
\text { instead of the now- } \\
\text { common abstractions } \\
\text { that are too-often made } \\
\text { about individuals (for } \\
\text { an important critique of } \\
\text { these abstractions, } \\
\text { which has still not } \\
\text { adequately been } \\
\text { answered but would be } \\
\text { if our propositions are } \\
\text { developed, see: } \\
\text { Willmott, 2011) }\end{array}$ \\
\hline
\end{tabular}




\begin{tabular}{|c|c|c|c|}
\hline & & $\begin{array}{l}\text { to every individual. } \\
\text { This mutually agreed } \\
\text { form for individual } \\
\text { responsibility is the flip } \\
\text { side of the attribution } \\
\text { of blame. }\end{array}$ & \\
\hline $\begin{array}{l}\text { Implicit Meanings } \\
\text { (Douglas, 1975) }\end{array}$ & $\begin{array}{l}\text { An introduction to } \\
\text { Douglas's thinking in } \\
\text { three parts. }\end{array}$ & \multirow[t]{3}{*}{$\begin{array}{l}\text { Boundaries can be used } \\
\text { forensically because } \\
\text { they reveal how order } \\
\text { is created }\end{array}$} & $\begin{array}{l}\text { The capacity to } \\
\text { compare institutions } \\
\text { across cultures without } \\
\text { resorting to ethnocentric } \\
\text { assumptions about } \\
\text { individuals (a problem } \\
\text { that was articulated by } \\
\text { Meyer, 2008) }\end{array}$ \\
\hline $\begin{array}{l}\text { Edward Evans- } \\
\text { Pritchard } \\
\text { (Douglas, 1980) }\end{array}$ & $\begin{array}{l}\text { The allocation of } \\
\text { responsibility for } \\
\text { misfortune }\end{array}$ & & \multirow{2}{*}{$\begin{array}{l}\text { A 'forensic' method for } \\
\text { tracing how } \\
\text { accountability is } \\
\text { allocated by } \\
\text { institutional thinking } \\
\text { (on method and for a } \\
\text { discussion about using } \\
\text { risk see: Douglas, 1990) }\end{array}$} \\
\hline $\begin{array}{l}\text { Thought Styles } \\
\text { (Douglas, 1996b) }\end{array}$ & $\begin{array}{l}\text { Why different people } \\
\text { reason differently in } \\
\text { everyday life }\end{array}$ & & \\
\hline $\begin{array}{l}\text { Purity and Danger } \\
\text { (Douglas, 1966) }\end{array}$ & $\begin{array}{l}\text { An attempt to } \\
\text { generalise from Africa } \\
\text { to our own condition }\end{array}$ & \multirow[t]{3}{*}{$\begin{array}{l}\text { Classification in } \\
\text { different societies as } \\
\text { this relates to social } \\
\text { conventions }\end{array}$} & \multirow{3}{*}{$\begin{array}{l}\text { Case studies for: (1) } \\
\text { understanding } \\
\text { Douglas's early } \\
\text { formulation of the } \\
\text { dynamics between } \\
\text { classification and order; } \\
\text { (2) how detailed } \\
\text { descriptions of social } \\
\text { organization can be } \\
\text { achieved }\end{array}$} \\
\hline $\begin{array}{l}\text { Rules and } \\
\text { Meanings } \\
\text { (Douglas, 1973b) }\end{array}$ & $\begin{array}{l}\text { A reader that } \\
\text { reinforces the } \\
\text { argument of Purity } \\
\text { and Danger }\end{array}$ & & \\
\hline $\begin{array}{l}\text { The Lele of the } \\
\text { Kasai } \\
\text { (Douglas, 1963) }\end{array}$ & $\begin{array}{l}\text { A collection of } \\
\text { ethnographic writings } \\
\text { from her fieldwork on } \\
\text { the Lele that provides } \\
\text { an analysis of their } \\
\text { organizational form }\end{array}$ & & \\
\hline $\begin{array}{l}\text { Natural Symbols } \\
\text { (Douglas, 1970) }\end{array}$ & $\begin{array}{l}\text { Introduces Grid-and- } \\
\text { Group to describe the } \\
\text { relationship between } \\
\text { social classification } \\
\text { and membership }\end{array}$ & \multirow[t]{2}{*}{$\begin{array}{l}\text { Operationalises the } \\
\text { earlier theory of how } \\
\text { social order and the } \\
\text { behavioural/cognitive } \\
\text { conventions cohere to } \\
\text { make a world }\end{array}$} & \multirow{2}{*}{$\begin{array}{l}\text { A primer for } \\
\text { understanding how } \\
\text { Grid-and-Group can be } \\
\text { used as a heuristic } \\
\text { device for analysing } \\
\text { different kinds of } \\
\text { cultural bias that would } \\
\text { be compared when } \\
\text { doing institutional }\end{array}$} \\
\hline $\begin{array}{l}\text { Cultural Bias } \\
\text { (Douglas, 1978) }\end{array}$ & $\begin{array}{l}\text { Summary and } \\
\text { refinement of Grid- } \\
\text { and-Group. }\end{array}$ & & \\
\hline
\end{tabular}




\begin{tabular}{|c|c|c|c|}
\hline $\begin{array}{l}\text { Essays in the } \\
\text { sociology of } \\
\text { perception } \\
\text { (Douglas, 1982a) }\end{array}$ & $\begin{array}{l}\text { A collection of essays } \\
\text { that apply Douglas's } \\
\text { model to a wide range } \\
\text { of topics }\end{array}$ & & $\begin{array}{l}\text { analysis. A wide range } \\
\text { of secondary sources } \\
\text { can be read alongside } \\
\text { this (e.g. Law, 1986; } \\
\text { Thompson, Grendstad, }\end{array}$ \\
\hline $\begin{array}{l}\text { The World of } \\
\text { Goods } \\
\text { (Douglas \& } \\
\text { Isherwood, 1996) }\end{array}$ & $\begin{array}{l}\text { Extends the argument } \\
\text { to consumption }\end{array}$ & & Wuthnow et al., 1984) \\
\hline $\begin{array}{l}\text { Risk Acceptability } \\
\text { According to the } \\
\text { Social Sciences } \\
\text { (Douglas, 1986b) }\end{array}$ & \multirow{3}{*}{$\begin{array}{l}\text { Extends the argument } \\
\text { to judgments about } \\
\text { risk. Risk } \\
\text { Acceptability is and } \\
\text { introduction to Risk } \\
\text { and Culture (see also: } \\
\text { Douglas, 2013a) }\end{array}$} & \multirow[t]{3}{*}{$\begin{array}{l}\text { Shows how the } \\
\text { anthropological } \\
\text { analysis of public } \\
\text { beliefs can be extended } \\
\text { to our own case. }\end{array}$} & \\
\hline $\begin{array}{l}\text { Risk and Culture } \\
\text { (Douglas \& } \\
\text { Wildavsky, 1982) }\end{array}$ & & & \\
\hline $\begin{array}{l}\text { Risk and Blame } \\
\text { (Douglas, 1992) }\end{array}$ & & & \\
\hline $\begin{array}{l}\text { Missing Persons } \\
\text { (Douglas \& Ney, } \\
\text { 1998) }\end{array}$ & $\begin{array}{l}\text { Her theory of } \\
\text { personhood and } \\
\text { agency (see important } \\
\text { discussion by Munro, } \\
\text { 1997) }\end{array}$ & \multirow[t]{2}{*}{$\begin{array}{l}\text { Against the critique of } \\
\text { reductionism and an } \\
\text { oversocialised } \\
\text { individual (cf. Wrong, } \\
\text { 1962) }\end{array}$} & \multirow{2}{*}{$\begin{array}{l}\text { The criticism of the } \\
\text { passive voice could } \\
\text { easily be extended and } \\
\text { applied to } \\
\text { organizational } \\
\text { institutionalism and all } \\
\text { its variants }\end{array}$} \\
\hline $\begin{array}{l}\text { In the Active Voice } \\
\text { (Douglas, 1982b) }\end{array}$ & $\begin{array}{l}\text { A collection of older } \\
\text { essays that impress the } \\
\text { necessity of not } \\
\text { treating humans as } \\
\text { passive and } \\
\text { impersonal objects }\end{array}$ & & \\
\hline
\end{tabular}

Figure 2: A thematic presentation of Mary Douglas's major works as they relate to the study of institutions.

\section{End-of-chapter exercises}

1. Think about the ways in which individuals are classified in and by organizations. How did these forms of classification come about? How does it affect the people who are classified in this way? Must we accept such classification or can we resist it?

2. Carefully consider Douglas's concepts of Grid and Group and think about how they might be used by you to understand your position in a social group and your relationship to others inside and outside the group. 
3. If institutions are social constructions then, conceivably, there could be an infinite number of different ones yet so few alternatives seem to present themselves at any one time. Why do you think this is case? How can Douglas help us to answer this question?

4. What alternatives are there to thinking of individuals as examples of Homo Economicus (i.e., the utility maximising, self-interested, rational actor)?

\section{Glossary}

Institution - Organizational studies refers to institutions as complex social forms that reproduce themselves. An organization is thus itself an institution but an organization's members live across many others such the family, religions, the legal system, governments, etc. For institutionalism to be a meaningful contribution to our understanding of organizations, however, it must be able to explain how they emerge, endure, change, and are ultimately replaced. In this sense, institutional analysis focuses on how individuals create but are also constrained by things like organizational structures (e.g., bureaucratic hierarchy), systems of rules, and taken-for-granted ways of behaving.

Rational actor - The idea of rational actor can be traced back to the origins of Western philosophy in ancient Greece but it is now most closely associated with a post-Enlightenment notion of humans who assess the costs and benefits of their action before making a decision. A variant of this in the limited circumstances of economic exchange is the rational, utility maximising, self-interested actor sometimes known as Homo Economicus.

Methodological individualism - The claim that social phenomena are best explained by showing how they result from the actions of individuals. In turn, those actions are best explained by developing an understanding of the specific intentional states that motivate the individual actors. As a form of atomism it is most closely associated with the work of Max Weber but it has become the dominant epistemological approach in many social science disciplines today, especially economics and social psychology. It stands in opposition to Emile Durkheim's notion of methodological holism where social phenomena cannot easily be explained by reducing them to the actions of individuals.

Social anthropology - An approach to the study of societies and cultures that focuses on the composition of social institutions and their interrelationships.

Durkheim (1858-1917) - A prominent and influential French sociologist who sought to explain how and why societies were able to maintain their integrity in a modern world in which traditional sources maintaining coherence and stability such as magic and religion no longer held sway.

Naturalization - A form of legitimization where a group tries to justify its preferred social arrangements by claiming they are a natural state of affairs. This may be strengthened by claiming additional support from ostensibly scientific evidence. For example, evolutionary psychology legitimates prevailing social arrangements by claiming they are part of our inherited human nature. 


\begin{abstract}
${ }^{1}$ Douglas (2013b, p. 15-36) describes this 'feeling for hierarchy' in a lecture she gives when she receives the Marianist award on 9 October 2001 to honour her as 'a Roman Catholic whose work has made a major contribution to the intellectual life'. It is important to note that one of Douglas's overall interests is in cultural bias, so rather than adopting a pro-hierarchical or anti-hierarchical attitude herself, she wants to understand what kind of culture leads to such attitudes.

${ }^{2}$ Max Weber borrows the term (Entzauberung) from Friedrich Schiller, to refer to the 'disenchantment' of the world, in a process of transformation from traditional to complex societies. He makes the analysis of this process one of the core problems he pursues throughout his work.

${ }^{3}$ DiMaggio's own ideas about cultural entrepreneurship owe much to Mary Douglas's early thinking about classification and framing (esp. Douglas, 1966, and the influence of Bernstein after this), as developed in her 'Mass Media and Mythology' seminar at the NYU Institute for the Humanities (see acknowledgments in: DiMaggio, 1982, p. 49, also fn. 3 p. 35).

${ }^{4}$ Four important thinkers who set the way for How Institutions Think are named in the preface: anthropologists E. Evans-Pritchard and Claude Lévi-Strauss and sociologists Émile Durkehim, and Robert Merton. Douglas dedicates the book to Merton. These are all figures who are now often too hastily dismissed with the label 'functionalists', a flippant charge which should not get the accuser off the hook from having to adequately engage with any of their primary texts (cf. Cummings et al., 2017; Hinings, Greenwood, \& Meyer, 2018;
\end{abstract} Thornton, 2009).

${ }^{5}$ Thornton, Ocasio, \& Lounsbury (2012) who wrote the first textbook on institutional logics, titling it The Institutional Logics Perspective, essentially ignored both the importance of Douglas's thought for Friedland \& Alford's (1991) conception of institutional logics and as Logue et al. (2016) argue, they and others ignored the importance of naturalising analogies for founding institutions. The literature on institutional logics has developed significantly since then and it has become highly differentiated, however the use of Douglas's work in this literature, which is what concerns us here, remains superficial.

${ }^{6}$ And similarly as a tribute to Lévy-Bruhl and Halbwachs for sociologizing the mind.

${ }^{7}$ In this note, Douglas (1986a, pp. $\mathrm{x}$-xi) gives us a personal insight into how she reconciles two incompatible problems: 'My husband deserves a special tribute. When two problems seem insoluble, our long experience of domestic life has suggested an oblique approach. Instead of a head-on attack on each separate issue, one set of problems can be made to confront the other. This strategy, which produces new definitions of what has to be solved, gives the framework of this book'.

${ }^{8}$ If Evans-Pritchard's work was to be held together as a sociological theory of knowledge, then Douglas maintains that there are three essays published in the Bulletin of the Faculty of Arts at the Egyptian University on the subjects of magic (Evans-Pritchard, 1933), comparison (Evans-Pritchard, 1934) and rationality (EvansPritchard, 1936) which exemplify this.

${ }^{9}$ The symmetry which Evans-Pritchard sought to promote between logic (reason and rationality), pre-logic (Lévy-Bruhl) and non-logic (Pareto) seemingly foreshadows the later problems of the sociology of scientific knowledge; local realities are to be anchored in local systems of accountability (Douglas, 1980, p. 35). Scientific culture is just as mystical as any other culture.

${ }^{10}$ This move is analogous to the one Bernstein makes when he turns his attention from restricted and elaborate speech codes to curriculum and the transmission of culture (e.g. Bernstein, 1996).

${ }^{11}$ Douglas says that this second edition of Natural Symbols 'shows up more obviously as the other side of [Bernstein's] thesis' (Douglas, 1996a, p. ix). What she means is that the relationship between ritual and restricted code in her work - that weak boundaries are associated with ritualism - is the reverse of what it is in Bernstein's. In this edition, grid also changes so that it is 'the scope and coherent articulation of a system of classification' (Douglas, 1996a, p. 59) whilst maintaining Durkheim's thesis that systems of classification are products of social relations.

${ }^{12}$ Eggers was an economist who received his $\mathrm{PhD}$ from Yale in 1950.

${ }^{13}$ A very similar foreword appears in other books that were published from this series (e.g. Calabresi, 1985; Coleman, 1982; Dahl, 1985; Hoffmann, 1981). Douglas also writes in her preface that some of the chapters were previously tested in other venues, including importantly a conference in memory of Nelson Goodman, the Hollingshead Lecture at Yale University, the American Sociological Association meeting and the ethics seminar series organized by the late Russell Hardin (editor of the journal Ethics at the time) at the University of Chicago.

${ }^{14}$ Careful readers of Douglas and Barnard will know that Douglas is using Barnard here as a linchpin to critique the institutional economists and not Barnard himself. This has the unfortunate effect of appearing as though she is overly critical of Barnard when in fact we believe that it is his interpreters that she sees as the real problem. 
${ }^{15}$ This passage in Douglas (2005, p. 95) reveals a certain kind of ethos that is not unlike what du Gay (2015) refers to as a classical stance in organization theory: 'I see [hierarchy] as a spontaneously created and maintained inclusive system, organizing its internal tensions by balance and symmetry, and rich in resources for peace and reconciliation. I miss it when it is not there, and grieve when it falls into any of its besetting traps'. 


\section{REFERENCES}

Abrams, F. W. (1951). Management's Responsibilities in a Complex World. Harvard Business Review, 29(3), 29-34.

Barnard, C. I. (1938). The functions of the executive. Cambridge: Harvard University Press.

Barnes, S. B. (1983). Social Life as Bootstrapped Induction. Sociology, 17(4), 524-545.

Beidelman, T. O. (1980). The ethnographer as translator. Evans-Pritchard by Douglas, Mary (author). The Times Literary Supplement, December 12(4054), 1420.

Bernstein, B. (1996). Pedagogy, symbolic control, and identity: theory, research, critique. London: Taylor \& Francis.

Bloor, D. (1978). Polyhedra and the Abominations of Leviticus. The British Journal for the History of Science, 11(3), 245-272.

Bryant, L. R., Srnicek, N., \& Harman, G. (2011). Towards a speculative philosophy. In L. R. Bryant, N. Srnicek \& G. Harman (Eds.), The speculative turn: Continental materialism and realism (pp. -118). Melbourne: re.press.

Calabresi, G. (1985). Ideals, beliefs, attitudes, and the law: Private law perspectives on a public law problem. Syracuse: Syracuse University Press.

Coleman, J. S. (1982). The asymmetric society. Syracuse: Syracuse University Press.

Cornelissen, J. P., Holt, R., \& Zundel, M. (2011). The Role of Analogy and Metaphor in the Framing and Legitimization of Strategic Change. Organization Studies, 32(12), 17011716.

Cummings, S., Bridgman, T., Hassard, J., \& Rowlinson, M. (2017). A new history of management. Cambridge: Cambridge University Press.

Dahl, R. A. (1985). Controlling nuclear weapons: Democracy versus guardianship. Syracuse: Syracuse University Press.

Dewey, J. (1922). Human Nature and Conduct. An introduction to social psychology. London: George Allen \& Unwin.

DiMaggio, P. (1982). Cultural entrepreneurship in nineteenth-century Boston: the creation of an organizational base for high culture in America. Media Culture Society, 4(1), 3350 .

DiMaggio, P., \& Powell, W. W. (1991). Introduction. In W. W. Powell \& P. DiMaggio (Eds.), The New institutionalism in organizational analysis (pp. 1-38). Chicago: University of Chicago Press. 
Douglas, M. (1963). The Lele of the Kasai. London: Oxford University Press.

Douglas, M. (1966). Purity and danger: an analysis of concepts of pollution and taboo. London: Routledge \& K. Paul.

Douglas, M. (1970). Natural symbols: Explorations in cosmology. London: Barrie and Rockliff, Cresset Press.

Douglas, M. (1973a). Natural symbols: explorations in cosmology (2nd ed.). London: Barrie and Jenkins.

Douglas, M. (1973b). Rules and meanings: the anthropology of everyday knowledge: selected readings. Harmondsworth: Penguin Education.

Douglas, M. (1975). Implicit meanings: essays in anthropology. London: Routledge \& Paul.

Douglas, M. (1978). Cultural bias. London: Royal Anthropological Institute.

Douglas, M. (1980). Edward Evans-Pritchard. New York: Viking Press.

Douglas, M. (1982a). Essays in the sociology of perception. London: Routledge \& Kegan Paul, published in co-operation with the Russell Sage Foundation.

Douglas, M. (1982b). In the active voice. London: Routledge \& Kegan Paul.

Douglas, M. (1986a). How institutions think. London: Routledge \& Kegan Paul.

Douglas, M. (1986b). Risk acceptability according to the social sciences. London: Routledge \& Kegan Paul.

Douglas, M. (1990). Risk as a forensic resource. Daedalus, 119(4), 1-16.

Douglas, M. (1992). Risk and blame: essays in cultural theory. London: Routledge.

Douglas, M. (1995). Converging on autonomy: Anthropology and institutional economics. In O. E. Williamson (Ed.), Organization theory: from Chester Barnard to the present and beyond (Expanded ed., pp. 98-115). New York: Oxford University Press.

Douglas, M. (1996a). Natural symbols: explorations in cosmology. London: Routledge.

Douglas, M. (1996b). Thought styles: Critical essays on good taste. London: Sage.

Douglas, M. (1999). Implicit meanings: selected essays in anthropology (2nd ed.). London: Routledge.

Douglas, M. (2001). Basil Bernstein. In B. Bernstein \& S. Power (Eds.), A tribute to Basil Bernstein, 1924-2000 (pp. 109-113). London: Institute of Education. 
Douglas, M. (2005). A feeling for hierarchy. In J. Heft (Ed.), Believing scholars: Ten Catholic intellectuals (pp. 94-120). New York: Fordham University Press.

Douglas, M. (2013a). Culture and crises: Understanding risk and resolution (Vol. 2). London: SAGE.

Douglas, M. (2013b). A very personal method: Anthropological writings drawn from life (Vol. 1). London: SAGE.

Douglas, M., \& Isherwood, B. C. (1996). The world of goods: towards an anthropology of consumption ([Rev. ed]. ed.). New York: Routledge.

Douglas, M., \& Ney, S. (1998). Missing persons: a critique of the social sciences. Berkeley: University of California Press.

Douglas, M., \& Wildavsky, A. (1982). Risk and Culture: An Essay on the Selection of Technical and Environmental Dangers. Berkeley: University of California Press.

du Gay, P. (2015). Organization (Theory) As A Way Of Life. Journal of Cultural Economy, $8(4), 399-417$.

Durkheim, É. (1951). Suicide: a study in sociology. Glencoe: Free Press.

Durkheim, É., \& Mauss, M. ([1903] 1963). Primitive classification. Chicago: University of Chicago Press.

Etzion, D., \& Ferraro, F. (2010). The Role of Analogy in the Institutionalization of Sustainability Reporting. Organization Science, 21(5), 1092-1107.

Evans-Pritchard, E. E. (1933). The intellectualist (English) interpretation of magic. Bulletin of the Faculty of Arts, I, 282-311.

Evans-Pritchard, E. E. (1934). Lévy-Bruhl's theory of primitive mentality. Bulletin of the Faculty of Arts, II, 1-36.

Evans-Pritchard, E. E. (1936). Science and sentiment: An exposition and criticism of the writings of Pareto. Bulletin of the Faculty of Arts, Part 2, 163-192.

Evans-Pritchard, E. E. (1951). Social anthropology. London,: Cohen \& West.

Evans-Pritchard, E. E. (1965). Theories of primitive religion. Oxford: Clarendon Press.

Fardon, R. (1987). The Faithful Disciple: On Mary Douglas and Durkheim. Anthropology Today, 3(5), 4-6.

Fardon, R. (1999). Mary Douglas: an intellectual biography. London: Routledge. 
Friedland, R., \& Alford, R. R. (1991). Bringing Society Back In: Symbols, Practices, and Institutional Contradictions. In W. W. Powell \& P. DiMaggio (Eds.), The New institutionalism in organizational analysis (pp. 232-263). Chicago: University of Chicago Press.

Goody, J. (1995). The expansive moment: the rise of social anthropology in Britain and Africa, 1918-1970. Cambridge: Cambridge University Press.

Hinings, C. R., Greenwood, R., \& Meyer, R. (2018). Dusty Books? The Liability of Oldness. Academy of Management Review, 43(2), 333-343.

Hoffmann, S. (1981). Duties beyond borders: On the limits and possibilities of ethical international politics (1st ed.). Syracuse: Syracuse University Press.

Kuper, A. (1983). Anthropology and anthropologists: the modern British school (Rev. ed.). London: Routledge \& Kegan Paul.

Lakatos, I. (1963). Proofs and refutations. London: Nelson.

Law, J. (1986). Power, action, and belief: a new sociology of knowledge? London: Routledge \& Kegan Paul.

Loewenstein, J., Ocasio, W., \& Jones, C. (2012). Vocabularies and Vocabulary Structure: A New Approach Linking Categories, Practices, and Institutions. The Academy of Management Annals, 1-46.

Logue, D. M., Clegg, S., \& Gray, J. (2016). Social organization, classificatory analogies and institutional logics: Institutional theory revisits Mary Douglas. Human Relations, 69(7), 1587-1609.

Malinowski, B. (1922). Argonauts of the Western Pacific: An Account of Native Enterprise and Adventure in the Archipelagoes of Melanesian New Guinea. London and New York: Routledge and Kegan Paul.

Mamadouh, V. (1999). Grid-group cultural theory: an introduction. GeoJournal, 47(3), 395409.

March, J. G., \& Olsen, J. P. (1984). The New Institutionalism: Organizational Factors in Political Life. The American Political Science Review, 78(3), 734-749.

Mead, M. (1929). Coming of age in Samoa: a psychological study of primitive youth for western civilisation. London: Jonathan Cape.

Meyer, J. W. (2008). Reflections on institutional theories of organizations. In R. Greenwood, C. Oliver, R. Suddaby \& K. Sahlin (Eds.), The SAGE handbook of organizational institutionalism (pp. 790-811). Los Angeles: SAGE. 
Meyer, J. W., \& Rowan, B. (1977). Institutionalized Organizations: Formal Structure as Myth and Ceremony. The American Journal of Sociology, 83(2), 340-363.

Munro, R. (1997). The Consumption View of Self: Extension, Exchange and Identity. The Sociological Review, 44(1_suppl), 248-273.

Perrow, C. (1986). Complex organizations: A critical essay (3rd ed.). New York: Random House.

Radcliffe-Brown, A. R. (1935). On the Concept of Function in Social Science. American Anthropologist, 37(3), 394-402.

Richards, P. (2008). Mary Tew Douglas (1921-2007). American Anthropologist, 110(3), 404-407.

Schneider, D. M. (1981). Review: Edward Evans-Pritchard by Mary Douglas. American Anthropologist, 83(3), 719-721.

Sewell, G. (2018). Myths that Work: Toward a Mythology of Organizations and Organizing. In Ø. Ihlen \& R. L. Heath (Eds.), The Handbook of Organizational Rhetoric and Communication (pp. 155-168). Hoboken: Wiley-Blackwell.

Stocking, G. W. (1984). Dr. Durkheim and Mr. Brown: Comparative sociology at Cambridge in 1910. In G. W. Stocking (Ed.), Functionalism historicized: Essays on British social anthropology (pp. 106-130). Madison: University of Wisconsin Press.

Stocking, G. W. (1995). After Tylor: British social anthropology, 1888-1951. Madison: University of Wisconsin Press.

Swanson, D. L. (2008). Top managers as drivers for corporate social responsibility. In A. Crane (Ed.), The Oxford handbook of corporate social responsibility (pp. 227-248). Oxford: Oxford University Press.

Thompson, M., Grendstad, G., \& Selle, P. (1999). Cultural theory as political science. London: Routledge.

Thornton, P. H. (2009). The value of the classics. In P. S. Adler (Ed.), The Oxford handbook of sociology and organization studies: Classical foundations (pp. 20-36). Oxford: Oxford University Press.

Thornton, P. H., \& Ocasio, W. (2008). Institutional logics. In R. Greenwood, C. Oliver, K. Sahlin \& R. Suddaby (Eds.), The SAGE Handbook of Organizational Institutionalism (pp. 99-129). Los Angeles: SAGE.

Thornton, P. H., Ocasio, W., \& Lounsbury, M. (2012). The institutional logics perspective: A new approach to culture, structure and process. Oxford: Oxford University Press. 
Tracey, P., \& Creed, W. E. D. (2017). Beyond managerial dillemas: The study of institutional paradoxes in organization theory. In P. Jarzabkowski, W. K. Smith, A. Langley \& M. W. Lewis (Eds.), The Oxford handbook of organizational paradox (First edition. ed., pp. 162-177). Oxford: Oxford University Press.

Wildavsky, A. (1987). Choosing Preferences by Constructing Institutions: A Cultural Theory of Preference Formation. The American Political Science Review, 81(1), 4-21.

Williamson, O. E. (1990). Organization theory: From Chester Barnard to the present and beyond: Spring seminar: Papers. New York: Oxford University Press.

Williamson, O. E. (1995). Organization theory: from Chester Barnard to the present and beyond (Expanded ed.). New York: Oxford University Press.

Willmott, H. (2011). "Institutional Work" for What? Problems and Prospects of Institutional Theory. Journal of Management Inquiry, 20(1), 67-72.

Wrong, D. H. (1962). The over-socialized conception of Man in modern sociology. Psychoanalysis and the Psychoanalytic Review, 49(2), 53-69.

Wuthnow, R., Hunter, J. D., Bergesen, A., \& Kurzweil, E. (1984). Cultural analysis: The work of Peter L. Berger, Mary Douglas, Michel Foucault, and Jürgen Habermas. Boston: Routledge \& Kegan Paul. 